\title{
THE CLASSIFICATION SYSTEM OF THE FAMILY APIACEAE IN THE FLORA OF MONGOLIA
}

\begin{abstract}
At present time is family Apiaceae consists of 74 species and 37 genera, 5 subtribes belong to 12 tribes (4 clades) and 2 sub-families (Saniculoideae and Apioideae) disjunctly distributed in the Mongolian flora. We updated classification system of the family Apiaceae in the flora of Mongolia.
\end{abstract}

Keywords: Classification system, Apiaceae, flora, Mongolia

\section{INTRODUCTION}

The V.I. Grubov (1955) firstly registered 46 species, 26 genera in the family Apiaceae. Then, Ts. Jamsran et al (1972) reported to 14 species of 9 genera and D. Magsar \& U. Ligaa (1977) to 6 species of 4 genera, in addition to previous and D. Magsar \& U. Ligaa (1977) concluded the information and facts of classification, distribution, ecology and habitat on 53 species of 31 genera and V.I. Grubov (1982) on 55 species of 28 genera; N. Ulziykhutag (1984) on 65 species of 36 genera; D. Magsar et al (1986) on 58 species of 32 genera; and N. Ulziykhutag (1989) on 59

\section{MATERIALS AND METHODS}

The family Apiaceae specimens from the Herbarium (UBA) of the Institute of Botany, Mongolian Academy of Sciences, Herbarium (UBU) of the National University of Mongolia, Herbarium (PE) of the Institute of Botany, Chinense Academy of Sciences, Herbarium species of 30 genera.

The family Apiaceae family is one of the biggest families in the flora of Mongolia. Doing detailed systematical study of the family, we aimed to reveal species composition of the family in the flora of Mongolia, do morphological, ecological geographical analysis and molecul biological method of the each species, to compare some features used for identifying the taxa and revealing higher level relationships in the family, and to revise previous classification systems of the family (Urgamal, 2013).

(LE) Institute of Botany, Russian Academy of Sciences, Herbarium of the Tracy's of Texas University A\&M (USA) and as well as additional data, were.

The nomenclature and taxonomy based followed works of Pimenov \& Leonov 
(1993), Vinogradova (1994), Menglan et al. (2005), Downie et al. (2010) and following professional taxonomic databases and websites: Angiosperm Phylogeny Group (APG
III, 2009), Angiosperm Phylogeny Website (APWeb, version 13. 2013), World Checklist of Selected Plant (WCSP), International Plant Names Index (IPNI) and W3 Tropicos (2013).

\section{RESULTS}

It is revealed that 74 species belonging to 37 genera, 5 subtribes, 12 tribes ( 4 clades) and 2 subfamilies (Saniculoideae and Apioideae) occur in the flora of Mongolia at present. We updated new conspectus and classification

system (according to Downie et al., 2010) of the family Apiaceae to the flora of Mongolia changed its system orders of tribes and genera (Urgamal, 2013).

Table 1

Classification system of the family Apiaceae in Mongolian flora

\begin{tabular}{|c|c|c|c|}
\hline Subfamilies & Tribes and clades & Subtribes & Gen./Sp. \\
\hline $\begin{array}{r}\text { 1. Saniculoideae } \\
\text { Burnett } 1835\end{array}$ & 1. Saniculeae W.D.J. Koch 1824 & $\begin{array}{l}\text { 1. Saniculinae Coss. \& } \\
\text { Germ. } 1845\end{array}$ & $1 / 1$ \\
\hline \multirow{16}{*}{$\begin{array}{l}\text { 2. Apioideae } \\
\text { Seem. } 1866\end{array}$} & 2. Bupleureae Spreng. 1820 & & $1 / 9$ \\
\hline & $\begin{array}{l}\text { 3. Pleurospermeae } \\
\text { M.F. Watson \& S.R. Downie } 2000\end{array}$ & & $2 / 2$ \\
\hline & Physospermopsis Clade & & $1 / 1$ \\
\hline & \multirow[t]{2}{*}{ 4. Scandiceae Spreng. 1820} & 2. Scandicinae Tausch 1834 & $2 / 2$ \\
\hline & & 3. Ferulinae Drude 1897 & $1 / 7$ \\
\hline & 5. Oenantheae Dumort. 1827 & & $3 / 4$ \\
\hline & Cachrys Clade & & $1 / 1$ \\
\hline & 6. Coriandreae W.D.J. Koch 1824 & 4. Coriandrinae Tausch 1834 & $1 / 1$ \\
\hline & 7. Pyramidoptereae Boissier 1872 & & $2 / 2$ \\
\hline & 8. Careae Baill. 1879 & & $2 / 3$ \\
\hline & 9. Pimpinelleae Spreng. 1820 & & $1 / 1$ \\
\hline & 10. Apieae Takht. ex V.M. Vinogr. 2004 & & $2 / 2$ \\
\hline & Acronem Clade & & $1 / 1$ \\
\hline & Sinodielsia Clade & & $3 / 5$ \\
\hline & 11. Selineae Spreng. 1820 & & $10 / 29$ \\
\hline & 12. Tordylieae W.D.J. Koch 1824 & 5. Tordyliinae Drude 1897 & $2 / 3$ \\
\hline 2 subfamilies & 12 tribe, 4 clade & 5 subtribe & $37 / 74$ \\
\hline
\end{tabular}

\section{References}

1. Angiosperm Phylogeny Group (APG) III. 2009. "An update of the Angiosperm Phylogeny Group classification for the orders and families of flowering plants: APG III". Botanical Journal of the Linnean Society. 161: 105-121.

2. Angiosperm Phylogeny Website. APW. 2013. [Online Database]. Version 13, updated by Febrary. 2013. URL: http://www.mobot.org/MOBOT/.

3. Downie, S.R., K. Spalik, D.S. Katz-Downie \& J.-P. Reduron. 2010. Major clades within

4. Apiaceae subfamily Apioideae as inferred by phylogenetic analysis of nrDNA ITS sequences. 
Plant Diversity and Evolution (formerly Botanische Jahrbscher) 128: 111-136.

5. Grubov, V. I. 1955. Konspekt flory Mongolskoy Narodnoy Respubliki. [Conspectus of the flora MNR]. Akademii Nauk SSSR, Moskva, Leningrad.: 308pp.

6. Grubov, V.I. 1982. Opredelitel sosudistyh rastenij Mongolii (s atlasom) [Key to the vascular plants of Mongolia (with an atlas)]. Leningrad, 191pp. (in Russian).

7. Gubanov, I. A. 1996. Konspekt flory vnesnej Mongolii [Survey of the flora of Outer Mongolia]. Moskva. 136p. (in Russian).

8. International Plant Names Index (IPNI) 2013. URL: http://www.ipni.org/ipni/=

9. Jansran, Ts., N. Ulziykhutag, Ch. Sanchir, 1972. Ulaanbaatar khot orchmiin urgamal tanikh bichig. [Key to the plants of the nearest of Ulaanbaatar city]. Ulaanbaatar, Mongolia.: 193198. (in Mongolian).

10. Magsar, D., U. Ligaa, 1977. Zontichnie v Mongolii. [Family Umbelliferae in Mongolia]. Bull. General and experimental Biology, Mongolian Academy of Sciences, vol. 12: 139154. (in Russian).

11. Magsar, D., Ch. Sanchir, A.I. Shreter 1986. Mongol orny Shukhertenii ovgiin urgamliin tarkhatsiin shine nutag. [New area of plants of the family Umbelliferae in Mongolia]. Proceedings of the Institute of Botany, Mongolian Academy of Sciences. vol. 8: 47-50. (in Mongolian).

12. Pimenov, M.G. \& M.V. Leonov. 1993. The genera of the Umbelliferae. Royal Botanic Gardens, Kew, UK.

13. Plunkett, G. M. \& S. R. Downie. 1999. Major lineages within Apiaceae subfamily Apioideae: a comparison of chloroplast restriction site and DNA sequence data. American Journal of Botany 86: 1014-1026.

14. Plunkett, G. M. 2001. Relationship of order Apiales to subclass Asteridae: A re-evaluation of morphological characters based on from molecular data. Edinburgh J. Bot. 8: 183-200.

15. She Menglan, Pu Fading, Pan Zehui, Mark F.Watson, John F.M.Cannon, Ingrid HolmesSmith, Eugene V.Kljukov, Loy R.Phillippe, Michael G.Pimenov 2005. Apiaceae (Umbelliferae) Flora of China, tomus 14: 205pp.

16. Ulziykhutag, N. 1984. Mongol orniy guurst urgamliin latin-mongol-oros neriin toli. Ulsiin ner tomiyonii komissiin medee, №129-133. - Ulaanbaatar., 445p. (in Mongolian).

17. Ulziykhutag, N. 1989. Mongol orniy urgamliin aimgiin toim. Ulaanbaatar. (in Mongolian).

18. Urgamal, M. 2009. Flora of Mongolia. vol. 10 (Apiaceae-Cornaceae). Ulaanbaatar, "Bembi san", 130pp. (in Mongolian).

19. Urgamal, M. 2013. Plant of the family Apiaceae in the Mongolian flora. Dissertation of the doctor degree of Biologcal Sciences. Ulaanbaatar.: 132pp. (in Mongolian).

20. Vinogradova, V.M. 1994. Plantae Asie Centralis. (Araliaceae, Umbelliferae, Cornaceae) Sankt.-Petersburg, T. 10: 41-42. (in Russian).

21. W3 Tropicos. 2013. [Online Database]. Missouri Botanical Garden. MOBOT. http://www. tropicos.org/. (Last updated: March, 2013).

22. World Checklist of Selected Plant (WCSP). 2013. [Online Database]. Facilitated by the Royal Botanic Gardens, Kew. http://apps.kew.org/wcsp/ (Last updated: Apr., 2013). 